Отримано: 10 липня 2019 р.

Прорецензовано: 15 липня 2019 р.

Прийнято до друку: 17 липня 2019 р.

e-mail: stanibula.stepan@mail.ru

DOI: $10.25264 / 2415-7384-2019-9-16-19$
Stepan Stanibula. Formation of productive coping behavior at students. Наукові записки Національного університету «Острозька академія». Серія «Психологія» : науковий журнал. Острог : Вид-во НаУОА, серпень 2019. № 9. С. 16-19.

\title{
FORMATION OF PRODUCTIVE COPING BEHAVIOR AT STUDENTS
}

The focus of the paper is made on the role and importance of productive coping behavior of students in the periods of crisis in the learning process while getting higher education. The author's training experience in the formation of productive coping behavior of students is presented. The effectiveness used in the framework of psychological training tools and techniques while working with students is also explained and proved.

Keywords: students, coping behavior, crisis, crisis state and condition, psychological training, psychosocial support, effective coping behavior.

\author{
Станібула Степан Олександрович, \\ стариий викладач кафедри психології \\ Гомельського державного університету імені Ф. Скорини
}

\section{ФОРМУВАННЯ ПРОДУКТИВНОЇ КОПІНГ-ПОВЕДІНКИ У СТУДЕНТІВ}

У статті розкрито роль і значущість продуктивної копінг-поведінки студентів у період криз навчання у вищзому навчальному закладі. Подано авторський тренінг формування продуктивної копінг-поведінки у студентів. Доведено ефективність використаних під час психологічного тренінгу засобів і методів у роботі зі студентами.

Ключові слова: студенти, копінг-поведінка, криза, кризовий стан, психологічний тренінг, сочіально-психологічний супровід, продуктивна копінг-поведінка.

A crisis in life is a situation that causes obstacles to the realization of internal motives, needs, goals due to the emergence of objective and subjective factors and conditions. A person has a habit of certain (traditional) forms of vital activity, living conditions, social status, moral and spiritual values, which ultimately constitute the basic foundation of his vital activity. A crisis can deprive him of this support. At the same time, along with negative manifestations, during a crisis, a deep understanding of the true value of life, spiritual self-awareness.

Literature review. A crisis in life is a situation that causes obstacles to the realization of internal motives, needs, goals due to the emergence of objective and subjective factors and conditions. A person has a habit of certain (traditional) forms of vital activity, living conditions, social status, moral and spiritual values, which ultimately constitute the basic foundation of his vital activity. A crisis can deprive him of this support. At the same time, along with negative manifestations, during a crisis, a deep understanding of the true value of life, spiritual self-awareness.

Organization of the research. The purpose of our research was to develop and experimentally test a program for the formation of productive coping among students. The practical significance of the results of work is determined by the pronounced applied significance of the formation of productive coping of students. The developed program was carried out in several stages, which is reflected in the table.

Chart - Experimental program "Formation of productive coping of students"

\begin{tabular}{|c|c|c|c|}
\hline Stage & Purpose & Means, methods & Result \\
\hline Diagnostic & $\begin{array}{l}\text { Identify individual } \\
\text { coping of students }\end{array}$ & $\begin{array}{l}\text { Method of determining individual coping strategies E. } \\
\text { Khaimah }\end{array}$ & $\begin{array}{l}\text { Identified individual } \\
\text { coping of students }\end{array}$ \\
\hline \multirow{3}{*}{$\begin{array}{l}\text { Procedural } \\
\text { developing }\end{array}$} & \multirow{3}{*}{$\begin{array}{l}\text { Increase the level } \\
\text { of individual } \\
\text { coping }\end{array}$} & $\begin{array}{l}\text { Training session «Working with the cognitive aspect of } \\
\text { personality» }\end{array}$ & \multirow{3}{*}{$\begin{array}{l}\text { Level of individual } \\
\text { coping is increased }\end{array}$} \\
\hline & & $\begin{array}{l}\text { Training sessions «Study and development of the } \\
\text { emotional sphere of the personality» }\end{array}$ & \\
\hline & & Training sessions «Behavioral aspects of personality» & \\
\hline $\begin{array}{l}\text { Evaluative } \\
\text { reflexive }\end{array}$ & $\begin{array}{l}\text { Set the final level } \\
\text { of formation of } \\
\text { productive coping }\end{array}$ & $\begin{array}{l}\text { Re-diagnosis (method of determining individual coping } \\
\text { strategies E. Khaimah), individual and group interviews } \\
\text { with students }\end{array}$ & $\begin{array}{l}\text { The obtained } \\
\text { experimental results } \\
\text { are analyzed. Practical } \\
\text { recommendations for } \\
\text { students are given. }\end{array}$ \\
\hline
\end{tabular}


During the diagnostic stage were determined the individual coping. For this, a sample study of 40 people was formed, represented by students of the Faculty of Psychology and Pedagogy Gomel State University named after Francis Skorina. The sample was represented by students of the second, third and fourth years. The uses method [7] allowed to determine the level of the following indicators: cognitive coping, emotional coping, behavioral coping. These results have the following gradation figures: productive coping (help to quickly and successfully cope with stress); relatively productive coping (helping in some situations, for example, not very significant or under slight stress); unproductive coping (does not eliminate a stressful state, on the contrary, contributes to its strengthening).

Results and their analysis. The productive coping were identified $42.5 \%$ of the test subjects, $27.5 \%$ relatively productive coping, 30\% unproductive coping. Recall that relatively productive coping help in some situations, for example, not very significant or with a little stress. It can be argued that most of the students have a low tolerance to stressful conditions (picture 1).

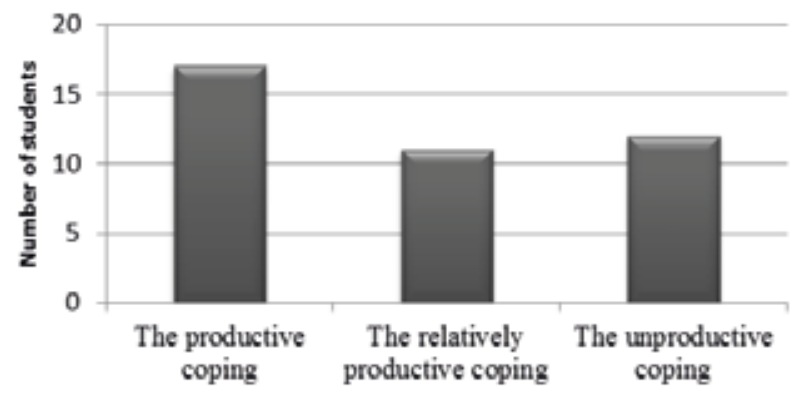

\section{Picture 1- Number of students with different cognitive coping}

The productive coping were identified $35 \%$ of the test subjects, $37.5 \%$ relatively productive coping and $27.5 \%$ unproductive coping. Although this is not part of the objectives of our study, it can be argued that emotional coping is lower than cognitive, it can be argued about a certain emotional perspective (picture 2).

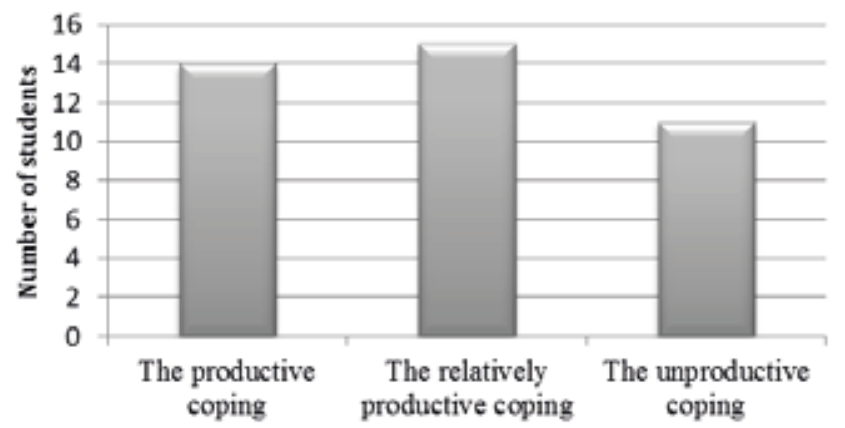

Picture 2 - Number of students with different emotional coping

The productive coping were identified $30 \%$ of the test subjects, $40 \%$ relatively productive coping, $30 \%$ unproductive coping. It is seen that in the aggregate $70 \%$ of the test subjects did't have productive coping (picture 3). The diagnostics were selected students with the lowest values of the studied parameters, which were invited to participate in a pilot study aimed at the formation of a productive coping.

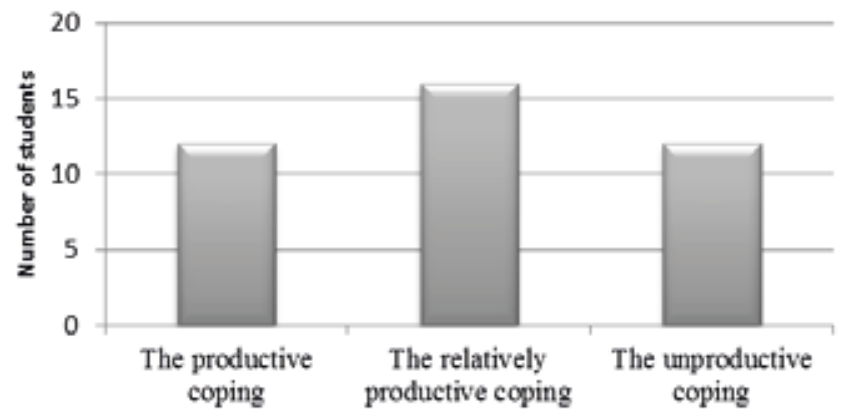

Picture 3 - Number of students with different behavioral coping 
The procedural development unit consisted of 3 training sessions, 2 days in length, 3.5-4 hours long. Remedial work was carried out by means of metaphorical associative cards. Metaphorical associative cards are used effectively in the psychodrama, Gestalt therapy, art therapy, transactional analysis and psycho-synthesis. The following types of metaphorical cards: «OH-CARDS», «PERSONA», «HABITAT», «ECCO», «MORENA», «MYTHOS», «SAGA», «1001», «SHEN HUA», «PERSONITA», «COPE», «CLARO», «QUISINE», «BOSCH»,«LYDIA JACOB STORY», «TAHITI», «BEAUREGARD» [8]-[9]. Associative card decks are sets of picture-pictures in card format. This is a set of cards depicting the reality around us (people, nature, household items, etc.) Associative metaphorical cards are an innovative tool, which is based on "classic" psychological phenomenon. The client works with the analysis and interpretation of their own associations that have arisen in the image. One of the fundamental mechanisms for the operation of cards is the law of projection. In fact, the cards are a stimulus, causing a flow of associations containing information about the inner world of a person; One of the fundamental mechanisms for the operation of maps is the law of projection. In fact, the cards are a stimulus, causing a flow of associations containing information about the inner world of a person; object, which is superimposed on the projected material. Projection (Latin projectio - throwing forward) is a psychological process attributed to the mechanisms of psychological defense, as a result of which the internal is mistakenly perceived as coming from outside. A person ascribes to someone or something his own thoughts, feelings, motives, character traits, etc., believing that he has perceived something coming from outside, and not from within himself [10].

The training sessions are aimed at activating group interaction, consciously using and mobilizing social resources to overcome their problems, developing creativity, which ultimately leads to the formation of productive-coping.

The evaluation of the effectiveness of the experimental program was carried out using the final diagnosis of the definition of individual coping strategies of E. Khaimah, the results of which revealed statistically significant improvements in the indicators of the parameters studied.

The diagram presented in Picture 4 reflects a significant improvement in the results in terms of cognitive coping strategies. In particular, we managed to form productive coping strategies and the number of unproductive coping strategies decreased significantly (by 16\%).

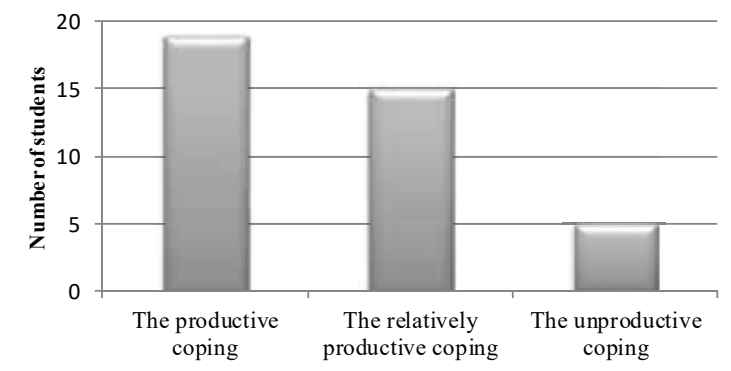

\section{Picture 4 - Number of students with different cognitive coping strategies at the end of the experimental program}

The results of productive coping strategies increased $7.5 \%$ and unproductive decreased by $17.5 \%$ (picture 5).

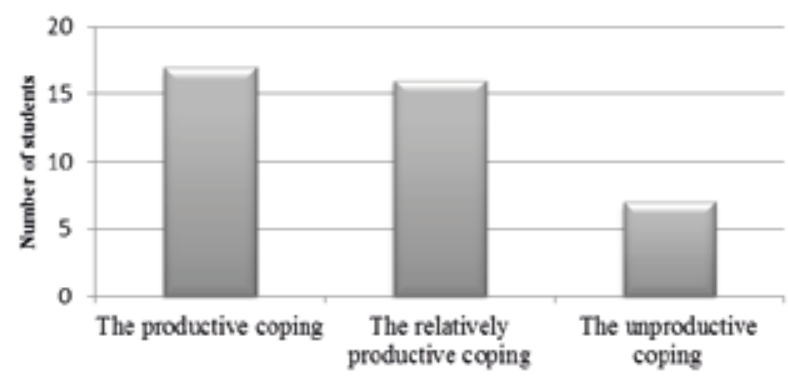

Picture 5 - Number of students with different emotional coping strategies at the end of the experimental program

In this component, we observe the most significant results, in particular, productive coping strategies increased by $16 \%$. Unproductive coping strategies have decreased significantly, in particular, by $16 \%$. 


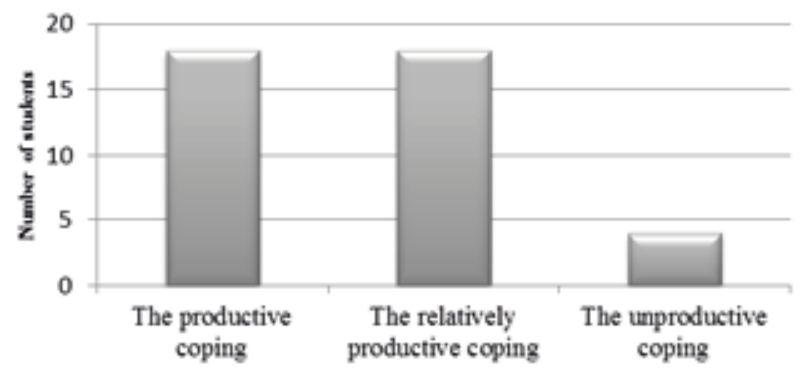
Picture 6 - Number of students with different behavioral coping strategies
at the end of the experimental program

The results obtained confirmed the realization of the purpose and objectives of the research. At the end completion of testing the experimental program, an improvement in individual values for the studied parameters was noted. So, for all three types: cognitive, emotional, behavioral coping strategies - an indicator of productive coping strategies increased: cognitive by $5 \%$; emotional by $7.5 \%$; behavioral coping strategies $16 \%$.

In terms of relatively productive coping strategies, we have the following results: in terms of cognitive performance, we have an increase from $30 \%$ to $40 \%$ for the total sample; on emotional indicator, we have an increase from $37.5 \%$ to $40 \%$; regarding behavioral coping strategies, we can observe an increase in dynamics from $40 \%$ to $45 \%$.

In terms of unproductive coping strategies, we observe the following results: in terms of the cognitive indicator, we have a decrease from $30 \%$ to $15 \%$ for the total sample; according to the emotional indicator, we have a decrease from $27.5 \%$ to $17.5 \%$; regarding behavioral coping strategies, we can observe the dynamics of decline from $30 \%$ to $10 \%$.

It can be said with confidence that the program has shown its effectiveness not only in the aspect of the formation of productive coping strategies, but also, as the results show, considerable success has been achieved in the aspect of correcting unproductive coping strategies.

Thus, the results of the research allow us to conclude about the effectiveness of the developed program for the formation of productive coping among students and the feasibility of its use in the system of social and psychological support for students during their studies in higher educational institutions.

\section{References}

1. Vygotsky L. S. Pedagogical psychology / by ed. V.V. Davydov. M.: Pedagogy, 1991. 480 p.

2. Vasilyuk F. E. Psychology of experiencing (analysis of overcoming critical situations). - Moscow: Moscow University Press, 1984. 200 p.

3. Boronova G. X., Prusova N. V. Labor psychology. Lecture notes. M.: Publishing house Eksmo, 2008. 160 p.

4. Kruger, A. Themidlifetransition: crisisorchimera. Psychologicalreports. 1994. Dec. 75. P. 1299-1305.

5. Lazarus R. S. Psychological stress and the coping process. New York : McGraw, 1966. 258 p.

6. Ponikarova V. N. Comparative study of professional coping of teachers-speech pathologists: monograph. Cherepovets: GOU VPO Chelyabinsk State University, 2011. P. 48-59.

7. Nabiullina R. R. Tukhtarova I. V. Mechanisms of psychological defense and coping with stress (definition, structure, functions, types, psychotherapeutic correction): Proc. allowance. Kazan, 2003. P. 23-29

8. Gorobchenko A. E., Evmenchik M. S. MS Metaphorical associative cards in the work of a practical psychologist. Psychology. 2010. № 1. P. 25-28.

9. Gorobchenko A. E., Evmenchik M. S. Evmenchik, MS Unique decks of metaphorical associative cards. Adukatar. 2011. № 1 (19). P. 33-36.

10. Handout. To the theoretical-practical seminar "Associative-metaphorical cards in the arsenal of a practicing psychologist". M.: UnikDom, 2011. 70 p. 